Newfoundland and Labrador Studies

\title{
Rosalind Gill. Too Unspeakable for Words
}

\section{Melanie Hurley}

Volume 34, Number 1, 2019

URI: https://id.erudit.org/iderudit/1072443ar

DOI: https://doi.org/10.7202/1072443ar

See table of contents

Publisher(s)

Faculty of Arts, Memorial University

ISSN

1719-1726 (print)

1715-1430 (digital)

Explore this journal

Cite this review

Hurley, M. (2019). Review of [Rosalind Gill. Too Unspeakable for Words].

Newfoundland and Labrador Studies, 34(1), 177-181.

https://doi.org/10.7202/1072443ar viewed online.

https://apropos.erudit.org/en/users/policy-on-use/ 
rather than to record experience as it unfolded" (37) a component part of a broader shift in the Canadian class landscape? Likewise, ethnomusicologists will find the discussion of occupational music-making particularly compelling. Overall, this book represents a multidisciplinary intervention into the understanding of working-class culture in Atlantic Canada. It is commendable both for the breadth of the authors' research and for the success of their efforts to let the sources speak for themselves. Indeed, it is in this final effort that they are perhaps most successful. In the songs, stories, and poems presented in this collection, the voices of woods workers in Newfoundland and Labrador resound with great clarity.

\section{Reference}

High, Steven. One Job Town: Work, Belonging, and Betrayal in Northern Ontario. Toronto: University of Toronto Press, 2018.

Lachlan MacKinnon

Cape Breton University

Rosalind Gill. Too Unspeakable for Words. St. John's: Breakwater Books, 2017. ISBN 978-1-77103-106-6

Rosalind Gill's collection of short stories is a quick read, and it was one that I loved: this slender volume (only 153 pages in length) is full of powerful emotions, memorable characters, and intriguing, if relatively ordinary, scenarios. One may think that the collection's focus on local places and its aestheticization of the familiar, even mundane, parts of everyday life in this province make it generic since these elements appear in many of Newfoundland's cultural products. However, 
Too Unspeakable for Words goes far beyond the merely generic (and all of its negative connotations), as Gill skilfully uses these tropes to create touching, original tales. To be sure, Gill captures the feeling of life in this province through her characters, title, and settings, and she combines these elements with feminist concerns to create a series of stories that blend happiness with sorrow, comedy with despair, and create a raw, relatable, moving, and beautiful reading experience.

Gill's characters are not great heroes, but regular men, women, and children going about their days: they are everyday people who live full, eventful lives that a local reader can relate to through his or her experiences and cultural knowledge. A line in "Learning to Tango" accurately summarizes the lives of Gill's characters, as well as life in St. John's (if not the province) more generally. Describing her inability to grasp the concept of le néant, nothingness, the story's unnamed narrator explains, "It didn't make sense in a place like St. John's, where life is curious and intense, full of eye contact and quirkish remarks from strangers. There might be despair all around you, but not nothingness — far from it" (95). Having lived in St. John's for most of my life, and coming from a family that has lived here for generations, I can vouch for the colourfulness, liveliness, and sometimes offbeat nature of this city. While Gill's characters are certainly not glamorous - housewives, schoolgirls, office and sales clerks, fishermen - they are dynamic, spirited, and have a flare as unique and vibrant as St. John's itself. Most of them have obvious, albeit relatively common, flaws, such as Bette House in "Too Unspeakable for Words," who is snobbish and irritable due to her class aspirations, and Meaghan Roche in "The One I Got," who is the overbearing matriarch of the Roche family. The stories typically show their protagonists as vulnerable, whether the recently divorced Mary lusting after another woman's husband in "Carpenter's Secret," or the lonely narrator of "La Fachada" foolishly falling in love with Milagros, a young Cuban woman who tutors him in Spanish. Yet, even with their shortcomings Gill's characters can be strong, caring, and funny, as is rundown-but-persevering Georgina in "Consciousness Raising." Through her colourful but relatable characters, Gill 
captures the vivacity in this province amid the quotidian, and this quality makes her stories highly appealing and lovely to read.

This fullness of life and its concomitant emotions comprise one of the themes in the collection that is "too unspeakable for words," as it is hard to capture such vitality and "quirkishness" on the page, particularly without resorting to melodrama, hyperbole, or digressive expositions, yet Gill does so remarkably well. Aside from that one short, explicit remark in "Learning to Tango," Gill shows this quality through the characters' (realistic) actions and thoughts. Her stories explore powerful feelings, such as love, desire, disappointment, and grief, and depict significant, often intense, interpersonal relationships, including marriages, parent-child relationships, and female friendships. These emotions and relationships are ones that people often have difficulty understanding and describing, but Gill's tales nonetheless depict them convincingly and poignantly. The stories leave an impression of life in all its messy complexity, its sorrows, victories, and confusions, and this impression stays with the reader long after the specific words and details have faded from mind.

Gill's use of local, everyday settings, a common feature of Newfoundland literature, ensures the tales' ability to capture the province's vitality, and it also reminds readers of how the places we inhabit impact our lives. For example, "Too Unspeakable for Words" and "Learning to Tango" both take place in St. John's, and together they make casual references to several streets and landmarks, including Long's Hill, Water Street, Woolworths ("Too Unspeakable” 11, 14), Forest Road, the Narrows, and the Basilica ("Tango" 93, 94, 95, 101), and as these places are (presumably) familiar ones, the stories' narrators do not describe them, but simply mention them as a part of what they relay, making these mundane places a part of the reading experience. Furthermore, these sites connect the readers to the characters and the characters to one another. A reader from or who has spent a lot of time in St. John's can identify with the characters through his or her knowledge of and experiences with these sites, and, as some of the stories share locations, they create associations among the characters. For instance, the 
first two stories, "Too Unspeakable for Words" and "House Devil," primarily take place in Rabbittown, and the next story, "Consciousness Raising," focuses on Georgina, a character from Rabbittown who appears in the previous two stories. Locations are prominent, if routine, aspects of the characters' lives, just as they are in our own lives, and by unobtrusively weaving them into the stories Gill reveals the roles that place plays in structuring our lives, in forging connections between people, and even in bridging the gap between fiction and reality.

The collection also highlights women's voices and experiences by exploring domestic spaces and emphasizing private life far more than public life, effectively infusing Newfoundland literature with feminist concerns. Often, women's lives and experiences have remained hidden from view and their voices left unheard, especially if they lived outside of social norms or mainstream middle-class standards. These omissions from the historical and cultural records have led feminist scholars of all disciplines to uncover women's history, writings, arts, and cultural practices: these scholars work to express what has gone unspoken and has been unspeakable. The collection's title, then, is a clever and succinct expression of its main concerns. Significantly, a line about Georgina in the first story provides both this tale and the collection their shared name, and makes clear the collection's desire to showcase the previously hidden lives of women. The narrator of "Too Unspeakable for Words," Nancy House, says, "In the eyes of Graham's [the posh Protestant girls' school that Nancy and Georgina attend], girls like Georgina were too unspeakable for words. Unreformable" (11). The collection brings Georgina and other girls and women like her into focus, giving them voices and attention that literature has previously denied them. Thus, like the work of many feminist scholars, Gill's work is expressing what was once inexpressible. Notably, eight of the stories have female protagonists, and half of this number, namely, "Too Unspeakable for Words," "Consciousness Raising," "No Tears," and "Learning to Tango," are narrated by the protagonists speaking their own truths on their own terms. Additionally, many of the stories prominently feature domestic spaces that are sites of personal life and 
places that women have traditionally occupied and managed, such as kitchens, living rooms or front rooms, and bedrooms, and they show some ways in which women have used and may still use these spaces to maintain or dissolve their relationships with others. However, not just the stories with female protagonists emphasize feminine and feminist concerns - even the two with male protagonists, "The Sweetest Meadows" and "La Fachada," focus on family, romance, desire, and the domestic, rather than on traditionally masculine issues, such as career, adventure, or male friendships. For example, the narrator of "La Fachada" dwells on his time in Gabí and Rosa's house and his growing infatuation with the couple's daughter, rather than on the time he spends in the streets of Santiago, and his fantasy of becoming Milagros's husband includes planning renovations to the house (148). Finally, "Consciousness Raising" (one of my favourite stories in the collection) makes the collection's connection to feminism explicit. Not only does it humorously examine how feminist politics inspires Georgina to create a better life for herself, but, true to its name, it draws attention to the collection's feminist vein and the feminist possibilities that it suggests. All in all, feminist issues come together with the stories' reflections of and on life in Newfoundland to create a collection that connects with tradition, but that also expands on familiar elements of the province's literature to include contemporary political and social issues.

Too Unspeakable for Words is an excellent collection of short stories that is in conversation with the corpus of Newfoundland's cultural products. I highly recommend this book, especially to anyone invested in the local arts scene, life in Newfoundland, and/or with an interest in women's issues or feminist politics. I doubt you will be disappointed.

Melanie Hurley

Memorial University of Newfoundland 